\title{
Involvement of voltage-dependent calcium channels (VDCC) in the action of GnRH on GtH release in common carp (Cyprinus carpio L): comparison with $\mathrm{K}+$ action
}

\author{
T Mikolajczyk 1,2*, C Weil 1, P Epler 2, B Breton 1
}

1 INRA, Laboratoire de Physiologie des Poissons, Campus de Beaulieu, 35042 Rennes, France; 2 Agricultural Academy, Department of Ichthyobiology \& Fisheries, 30149 Crakow, Mydlniki, Poland

(Received 9 January 1990; accepted 20 July 1990)

\begin{abstract}
Summary - The involvement of different types of voltage-dependent calcium channels (VDCC) in the stimulatory action of $\mathrm{GnRH}$ (in comparison with $\mathrm{K}^{+}$) on maturational gonadrotropin (GtH) release was investigated using superfused carp pituitary cells. The action of these 2 stimulants was not modified either by D600 or nifedipine (drugs blocking L-type of VDCC). Cadmium ( $\mathrm{Cd}^{2+}$ ), which blocks all types of VDCC indifferently, provoked a dose-dependent stimulation of GtH secretion. Cd2+ action was not altered by addition of sGnRH in any of the doses. Similar results were obtained using $\mathrm{K}^{+}$as a secretagogue, but only the highest dose of $\mathrm{Cd}^{2+}(200 \mu \mathrm{mol} /)$ was able to completely block $\mathrm{K}^{+}$action. Low doses $(0.1$ and $1 \mu \mathrm{mol} / \mathrm{h})$ of the L-type VDCC activator BAY-K8644 did not change basal GtH secretion and had no effect on sGnRH-stimulated GtH secretion. Surprisingly, doses $(10 \mu \mathrm{mol} /$ and higher) of BAY-K8644 evoked dose-dependent inhibition of GtH secretion. On the other hand, a higher concentration $(20 \mu \mathrm{mol} / \mathrm{l})$ of nifedipine provoked a stimulation of GtH release.

Our results indicate that the stimulatory action of GnRH and $\mathrm{K}^{+}$involves activation of a certain type of cadmium-sensitive VDCC (probably T- or N-type VDCC) whereas dihydropyridine and diphenylalkylamine sensitive VDCC (L-type VDCC) does not participate in this phenomenon. The inhibitory action of BAY-K8644 and, on the other hand, the stimulatory action of nifedipine indicate that L-type VDCC probably play a role in other physiological pathways regulating $\mathrm{GtH}$ release in carp.
\end{abstract}

GnRH / GtH / calcium channel / carp

Résumé - Implication de canaux calciques dont l'action dépend du voltage (VDCC) dans l'action du GnAH sur la libération de la GtH chez la carpe commune (Cyprinus carpio L): comparaison avec l'action de $\mathrm{K}^{+}$. Le rôle de différents types de canaux calciques dépendants du voltage (VDCC) dans l'action du GnRH sur la stimulation de la sécrétion de gonadotropine (GtH) par des cellules dispersées d'hypophyse de carpe a été étudié dans un système de périfusion. Le mécanisme d'action du $\mathrm{GnRH}$ a été comparé à celui du potassium $\left(K^{+}\right)$. L'action de ces 2 facteurs n'est modifiée ni par le $D-600$ ni par la nifedipine qui bloque les VDCC de type L. Le cadmium (Cd ${ }^{2+}$ ) qui bloque indifféremment tous les VDCC induit une stimulation dont lintensité dépend de la sécrétion du GtH, qui n'est pas modifée en présence de GnRH et ce quelle que soit la concentration de $C d^{R+}$ Des résultats comparables sont obtenus avec $K^{+}$, mais seules de fortes concentrations de $C^{2+}(200$ umol/) bloquent l'action de $K^{+}$. De faibles doses de BAY-K8644, activateur des canaux de type $L$, ne modifient ni la sécrétion basale de GtH, ni l'action du GnRH, alors que de fortes doses (10 $\mu$ mol/n) induisent une inhibition dont l'intensité dépend de la sécrétion de GtH. Par ailleurs la nifedipine à 20 umoll stimule elle-même la sécrétion de GtH. Ces résultats montrent que l'action stimulante du

\footnotetext{
* Correspondence and reprints.
} 
GnRH et de $K^{+}$implique l'activation de certains types de VDCC sensibles au cadmium, sans doute de type $T$ ou $N$, les canaux sensibles aux dihydropiridine et diphényloalkylamine, de type L, n'étant pas mis en jeu dans ces phénomènes. Les actions inhibitrices du BAY-K8644, et stimulatrice de la nifedipine, montrent cependant que les canaux de type $L$ jouent sans doute un rôle dans d'autres mécanismes régulant la sécrétion de GtH.

GnRH / GtH / canaux calciques / carpe

\section{INTRODUCTION}

It is well established that calcium ions $\left(\mathrm{Ca}^{2+}\right)$ play the role of second messenger in GnRH action in mammals (Conn et al, 1987; Huckle and Conn, 1988). There are more and more reports indicating that $\mathrm{GnRH}$ action on $\mathrm{GtH}$ release is also a $\mathrm{Ca}^{2+-d e p e n d e n t ~ p r o c e s s ~ i n ~ f i s h ~(J a m a l u d-~}$ din et al, 1989; Levavi-Sivan and Yaron, 1989; Mikolajczyk et al, 1990). There is a general agreement that in higher vertebrates (birds and mammals), $\mathrm{Ca}^{2+}$ influx through voltage dependent calcium channels (VDCC) is responsible for prolonged LH secretion under GnRH stimulation. However, the spike phase of the secretory response to $\mathrm{GnRH}$ is independent of $\mathrm{Ca}^{2+}$ influx through VDCC (Hansen et al, 1987; Chang et al, 1986, 1988; Smith et al, 1987; Davidson et al, 1988; Smith et al, 1989). There could be an influx of $\mathrm{Ca}^{2+}$ through channels other than VDCC, the so-called receptor operated channels (ROC) (Conn et al, 1987; Davidson et al, 1988; Smith et al, 1989) or mobilization of $\mathrm{Ca}^{2+}$ from intracellular stores (Chang et al, 1986; Hansen et al, 1987). In fish literature there is also some controversy about the participation of VDCC in GnRH action. Jamaluddin et al (1989) observed in murrel a dose-dependent inhibition of GnRHstimulated GtH secretion by D-600 (VDCC blocker) present in the culture medium. On the other hand, Van Asselt et al (1989) found that D-600 had no effect on spontaneous and $\mathrm{GnRH}$-stimulated $\mathrm{GtH}$ release in African cattish, while such an inhibition was observed when nifedipine (another class of VDCC blockers) was used.

We have shown an extracellular $\mathrm{Ca}^{2+}$ dependence of $\mathrm{GnRH}$ action on $\mathrm{GtH}$ release in carp (Mikolajczyk et al, 1990). The aim of the present study was to compare the action of $\mathrm{sGnRH}$ with $\mathrm{K}^{+}$(elevated $\mathrm{K}^{+}$ evokes depolarizaton of cell membrane and activates VDCC) and to find out which type of VDCC participates in the stimulatory action of these 2 secretagogues on $\mathrm{GtH}$ release in carp.

\section{MATERIALS AND METHODS}

\section{Animals}

Experiments were conducted for 2 consecutive years (1988 and 1989) during the natural reproductive period of carp ie from Aprit to July. Sexually mature female carp breeders weighing $5.5-11.5 \mathrm{~kg}$ obtained from the Heyman Fish Farm were kept in natural ponds and then transported to the laboratory. They were placed in a thermoregulated recirculating water system and acclimated at $18^{\circ} \mathrm{C}$ for at least $10 \mathrm{~d}$ before being used in experiments. They were exposed to a controlled photoperiod (16L: 8D) and fed ad libitum with pelleted food (Aqualim).

\section{Cell preparation and perifusion system}

Cell preparation and the perifusion system were as previously described (Mikolajczyk et al, 1990). Briefly, pituitaries (1 pituitary for each perifusion) were dispersed using collagenase 
(0.1\%) (Boehringer Mannheim) in a medium (MEM-Eagle, Gibco) buffered with $15 \mathrm{mmol} / 1$ Hepes and $9 \mathrm{mmol} / \mathrm{l}$ sodium bicarbonate and supplemented with $1 \%$ BSA (RIA grade, Sigma). The mixture was incubated at $18^{\circ} \mathrm{C}$ for $6 \mathrm{~h}$, and dispersion was achieved mechanically. Cells were harvested by centrifugation, washed twice, mixed with Bio-Gel P-2 (Biorad) and placed in thermoregulated perifusion columns $\left( \pm 10^{6}\right.$ cells per column). Five columns could be perifused at the same time. The cells were perifused first for $18 \mathrm{~h}$ at a flow rate of $4 \mathrm{ml} / \mathrm{h}$ with the above medium supplemented with $2 \%$ of a serum substitute, Ultroser-SF (IBF), penicillin (100 U/ml) and streptomycin $(10 \mu \mathrm{g} / \mathrm{ml}$ ) (Gibco). The ultroser and antibiotics were then withdrawn and the flow rate was gradually increased up to $15 \mathrm{ml} / \mathrm{h}$. After 90 min of perifusion at a flow rate $15 \mathrm{ml} / \mathrm{h}$, the first pulse of the drugs was administered. Fractions were collected every $7.5 \mathrm{~min}$ before drug administration and every $2.5 \mathrm{~min}$ during and $15 \mathrm{~min}$ after drug application. Details concerning each perifusion are given in the figure legends.

\section{Drugs}

Salmon GnRH (sGnRH) (Bachem), veratridine (Sigma) and cadmium chloride were dissolved directly in the perifusion medium prior to use. Methoxyverapamil (D-600), nifedipine (Sigma) and BAY-K8644 (RBI) were dissolved in ethanol and then in the perifusion medium. The amount of ethanol in the medium never exceeded $0.15 \%$. The same amount of carrier was always present in the perifusion medium passing through control columns and had no measurable effect on GtH release. In experiments in which the effect of $\mathrm{K}+$ depolarization was tested, the amount of $\mathrm{NaCl}$ in the test medium was reduced accordingly so that the total concentration of $\mathrm{KCl}$ and $\mathrm{NaCl}$ remained constant.

\section{GtH determination and calculations}

GtH levels were determined using a specific RIA developed by Breton et al (1971).

Profiles of $\mathrm{GtH}$ secretion are presented as a mean percentage of the basal GtH secretion lev- el (bl). Basal level of GtH release (100\%) was calculated as the mean of the 4 points (fractions) directly preceding first drug application. Fluctuations of GtH levels during the period directly preceding all drug administration never exceeded $20 \%$ of the basal GtH secretion level. Fluctuations of $\mathrm{GtH}$ levels greater than 20\% were considered as significant. Differences in $\mathrm{GtH}$ secretion rate between the control and experimental columns during the stimulation period were calculated using Student's t-test for variation analysis.

\section{RESULTS}

\section{Effect of organic VDCC blockers on GnAH- and $K^{+-}$-stimulated GtH release}

As shown in figure $1 \mathrm{~A}$, two $15 \mathrm{~min}$ pulses of sGnRH $\left(10^{-7} \mathrm{~mol} / \mathrm{l}\right)$ evoked in the control columns a significant increase in GtH secretion $(300 \%$ bl). In the experimental columns, the infusion of $2 \mu \mathrm{mol} / /$ of VDCC blocker - D-600 (interfering mostly with Ltype VDCC) had no effect on sGnRHstimulated GtH release. A ten times higher $(20 \mu \mathrm{M})$ concentration of D-600 had no effect on sGnRH action (fig 1B) either.

At 2 and $20 \mu \mathrm{mol} / /$ concentrations, nifedipine, a specific L-type VDCC blocker had no effect on sGnRH-stimulated GtH release ( 448 and $310 \%$ bl) when administered in experimental columns in comparison with the control columns receiving sGnRH alone (432 and $350 \%$ bl) (fig 2). During the infusion of $20 \mu \mathrm{mol} / \mathrm{l}$ of nifedipine a significant increase $(P<0.01)$ in GtH secretion was observed $(300 \% \mathrm{bl})$.

A 12.5-min application of $\mathrm{KCl}(60 \mathrm{mM}$ of $\mathrm{K}^{+}$) resulted in a sharp increase (342 and $218 \%$ bl) in GtH secretion (fig 3 and data not shown). The amplitude and profile of the secretory response of the cells to elevated $\mathrm{K}^{+}$was similar to that caused by sGnRH (figs 1, 2 and 5). No significant dif- 

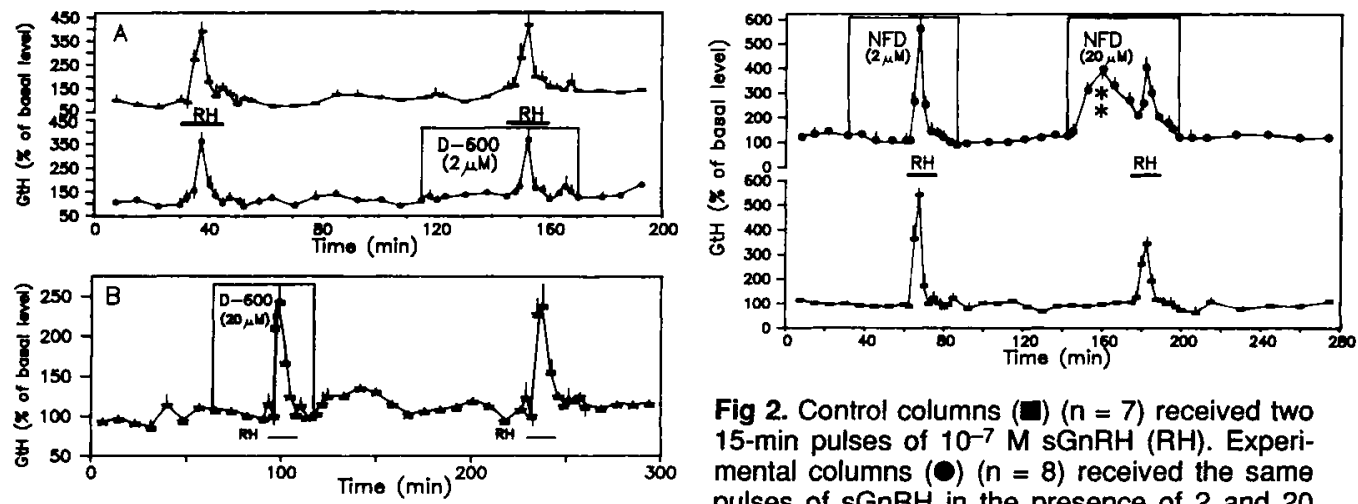

Fig 2. Control columns $(\square)(n=7)$ received two 15-min pulses of $10^{-7} \mathrm{M}$ sGnRH (RH). Experimental columns $(\Theta)(n=8)$ received the same pulses of sGnRH in the presence of 2 and 20 $\mu \mathrm{mol} / \mathrm{h}$ of nifedipine as indicated. Nifedipine was applied $30 \mathrm{~min}$ before pulse of sGnRH. Mean

Fig 1A. Control columns $(\square)(n=5)$ received two 15-min pulses of $10^{-7} \mathrm{M}$ sGnRH (RH). Experimental columns $(\Theta)(n=5)$ received the same pulses of sGnRH but the second one in the presence of $2 \mu \mathrm{mol} / /$ of D-600. D-600 was present in the perifusion chamber $30 \mathrm{~min}$ before sGnRH application as indicated. Mean basal GtH level of all the columns was $31.5 \pm 12.5 \mathrm{ng} /$ $\mathrm{ml}$. Data from 2 separate experiments. B. Eight columns (data from 2 experiments) received two $15 \mathrm{~min}$ pulses of $10^{-7} \mathrm{~mol} / \mathrm{l} \mathrm{sGnRH}(\mathrm{RH})$. The first one together with $20 \mu \mathrm{mol} / \mathrm{h}$ of $\mathrm{D}-600$ as indicated. D-600 was present in the perifusion chamber $30 \mathrm{~min}$ before $\mathrm{sGnRH}$ application. Mean basal GtH level was $18.3 \pm 8.3 \mathrm{ng} / \mathrm{ml}$.

ferences were observed between the control columns receiving pulses of $\mathrm{K}^{+}(60$ $\mathrm{mmol} / \mathrm{l})$ and the experimental columns receiving $\mathrm{K}^{+}$in the presence of nifedipine (2 $\mu \mathrm{mol} / \mathrm{l})$ or D-600 (2 $\mu \mathrm{mol} / \mathrm{l})$ (fig 3).

\section{Effect of $\mathrm{Cd}^{2+}$, an inorganic VDCC blocker, on spontaneous, sGnRH- and $\mathrm{K}^{+}-$stimulated $\mathrm{GtH}$ release}

A 30-min administration of graded doses of $\mathrm{CdCl}_{2}\left(20,100\right.$ and $200 \mu \mathrm{mol} / /$ of $\left.\mathrm{Cd}^{2+}\right)$ resulted in a dose-dependent increase in GtH secretion $(80,110$ and $170 \%$ bl respectively) (fig 4). In the case of higher concentrations of $\mathrm{Cd}^{2+}(100$ and $200 \mu \mathrm{mol} / \mathrm{l})$, the profile of $\mathrm{GtH}$ secretion exhibited a

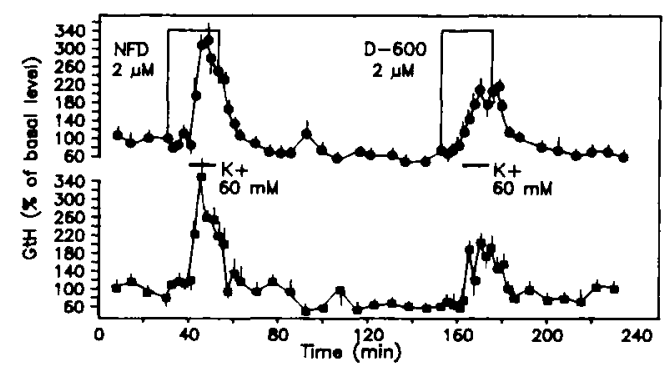

Fig 3. Control columns $(\square)(n=7)$ received two 12.5-min pulses of $\mathrm{K}^{+}(60 \mathrm{mM})$. Experimental columns $(\Theta)(n=8)$ received the same pulses of $\mathrm{K}+$ but in the presence of nifedipine or $\mathrm{D}-600$ as indicated. Nifedipine and D-600 were present in the perifusion chamber $10 \mathrm{~min}$ before $\mathrm{K}^{+}$application. Mean basal level of all the columns from 3 separate experiments was $36 \pm 20.7 \mathrm{ng} / \mathrm{ml}$.

characteristic biphasic response: first phase during the presence of $\mathrm{Cd}^{2+}$ in the perifusion chamber and second phase after $\mathrm{Cd}^{2+}$ withdrawal (figs $4,5 \mathrm{~A}$ and 6). When sGnRH (10-7 mol/l) was infused during the application of $\mathrm{Cd}^{2+}$ (20 and 200 $\mu \mathrm{mol} / \mathrm{l})$ no changes in $\mathrm{GtH}$ secretion were obtained in comparison with the control 


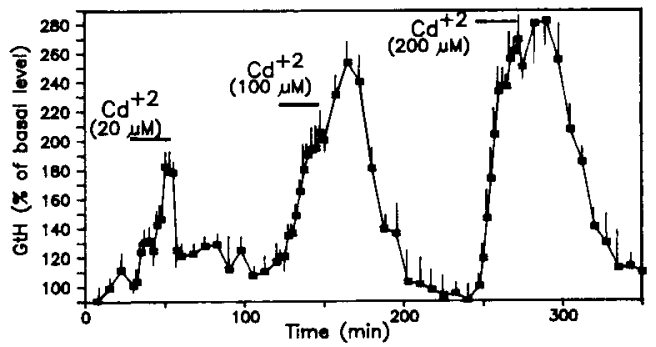

Fig 4. Graded doses of $\mathrm{Cd}^{2+}$ were administered as 25-min pulses as indicated. Data represent a mean of 12 columns ( 3 experiments). Mean basal GtH level was $43.4 \pm 17.8 \mathrm{ng} / \mathrm{ml}$.

columns receiving $\mathrm{Cd}^{2+}$ alone (fig $5 \mathrm{~A}$ ). To check if $\mathrm{Cd}^{2+}$ had any side effect on sGnRH action (experiment presented in fig 5B) a similar pulse of sGnRH (alone) was applied 60 min after $\mathrm{Cd}^{2}+$ withdrawal after joint administration of $\mathrm{Cd}^{2+}(20 \mu \mathrm{mol} / \mathrm{l})$ and sGnRH $\left(10^{-7} \mu \mathrm{mol} / 1\right)$. This resulted, in both the experimental and the control columns, in the stimulation of $\mathrm{GtH}$ secretion, having a similar potency in a manner similar to earlier experiments.

The results presented in figure 6 show that $60 \mathrm{mM}$ of $\mathrm{K}^{+}$modified $(P<0.05)$ a secretory response of the cells to $100 \mu \mathrm{mol} / /$ concentration of $\mathrm{Cd}^{2+}$ in comparison with the control columns, while no differences were observed between the control and experimental columns during $\mathrm{K}^{+}$stimulation when $200 \mu \mathrm{mol} / /$ of $\mathrm{Cd}^{2+}$ was applied.

\section{Effect of organic activators of VDCC on GtH release}

Veratridine (an organic membrane depolarizer) at a wide range of concentrations $(0.1$ to $10 \mu \mathrm{mol} / \mathrm{l})$ had no effect on $\mathrm{GtH}$ release (data not shown); a weak increase in GtH secretion $(30-50 \%$ bl) was observed when much higher doses were used (50
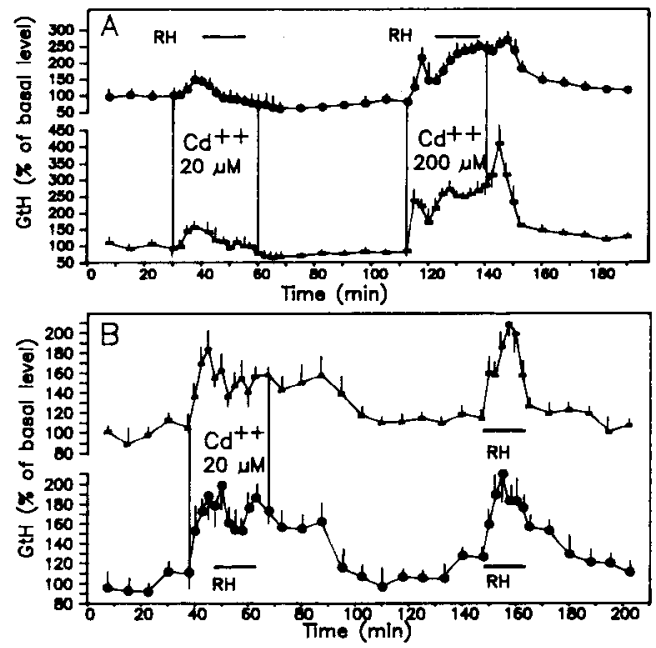

Fig 5A. Five control columns (A) as well as 5 experimental columns (O) were exposed to 2 graded doses of $\mathrm{Cd}^{2}+(20$ and $200 \mu \mathrm{mol} / \mathrm{l})$ for 30 min. In the experimental columns two 15-min pulses of $s \mathrm{GnRH}(\mathrm{RH})\left(10^{-7} \mathrm{~mol} / \mathrm{l}\right)$ were administered $10 \mathrm{~min}$ after the beginning of $\mathrm{Cd}^{2+}$ application as indicated. Mean basal GtH level of all the columns from 2 separate experiments was $25.1 \pm 15.0 \mathrm{ng} / \mathrm{ml}$. B. Control columns (I) $(n=$ 5) received a $30-\mathrm{min}$ pulse of $20 \mu \mathrm{mol} / / \mathrm{lof} \mathrm{Cd}^{2+}$ and $80 \mathrm{~min}$ later a $15 \mathrm{~min}$ pulse of $\mathrm{sGnRH}\left(10^{-7}\right.$ $\mathrm{mol} / \mathrm{RH})$. Experimental columns $(O)(n=5)$ received the same set of pulses as control columns but during the $\mathrm{Cd}^{2+}$ administration a 15 min pulse of $\mathrm{sGnRH}\left(10^{-7} \mathrm{~mol} / \mathrm{l}\right)(\mathrm{RH})$ was applied 10 min after the beginning of $\mathrm{Cd}^{2+}$ infusion as indicated. Mean basal GtH level of all the columns was $42.3 \pm 18.6 \mathrm{ng} / \mathrm{ml}$. Data from 2 separate experiments.

and $100 \mu \mathrm{mol} / 1$ respectively) (fig 7 ). The administration of BAY-K8644 (dihydropirydine, specific activator of L-type VDCC) in concentrations ranging from 0.01 to 1 $\mu \mathrm{mol} / \mathrm{l}$ caused no changes in $\mathrm{GtH}$ secretion (data not shown). BAY-K8644 at a concentration of $0.1 \mu \mathrm{mol} / /$ also had no effect on sGnRH-stimulated GtH secretion (data not shown). When BAY-K8644 was applied in concentrations of 10,20 and $40 \mu \mathrm{mol} / /$ it 


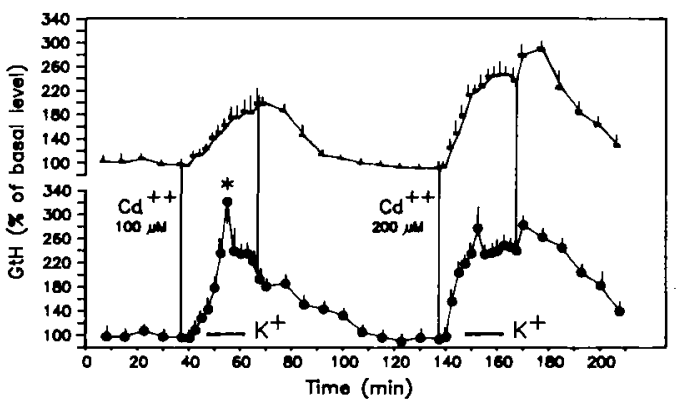

Fig 6. Control columns $(\square)(n=7)$ were exposed to graded doses of $\mathrm{Cd}^{2+}$ in pulses lasting 30 min. In experimental columns $(0)(n=8)$ two 15min pulses of $\mathrm{K}+(60 \mathrm{mM})$ were given $10 \mathrm{~min}$ after the beginning of $\mathrm{Cd}^{2+}$ application as indicated. Mean basal GtH level of all the columns from 3 separate experiments was $19.4 \pm 6.1 \mathrm{ng} /$ $\mathrm{ml}$ (See fig 2 for other details).

resulted in dose-dependent inhibition of GtH secretion - 28, 34 and $45 \%$ bl respectively (fig 8).

\section{DISCUSSION}

In recent years significant progress has been made in detailed characterization of the mechanism of $\mathrm{GnRH}$ action on gonadotropin release, mainly in rats and chickens; however there is more and more data concerning the mechanism of $\mathrm{GnRH}$ action in other groups of vertebrates, especially in fish (Levavi-Sivan and Yaron, 1989; Chang et al, 1989; Jamaluddin et al,

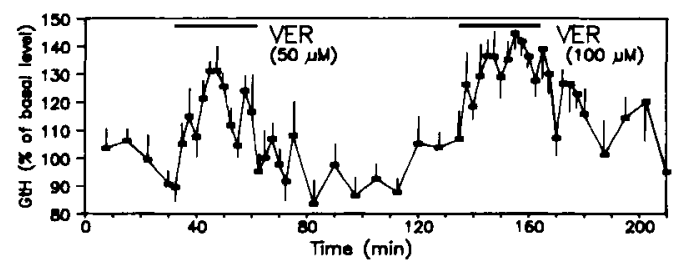

Fig 7. Eight columns (data from 2 experiments) received 2 pulses of graded doses of veratridine lasting $30 \mathrm{~min}$ as indicated. Mean basal $\mathrm{GtH}$ level was $26.3 \pm 8.5 \mathrm{ng} / \mathrm{ml}$.

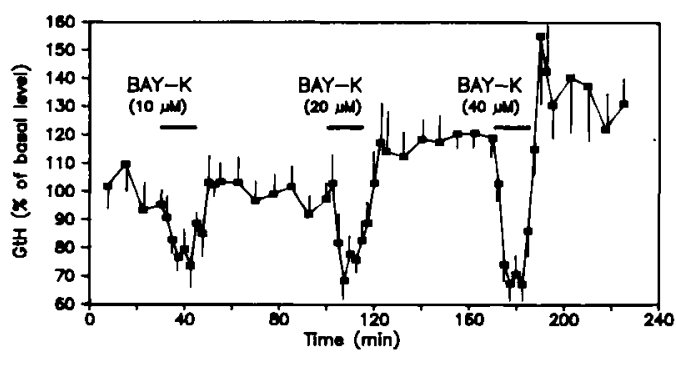

Fig 8. Cells received three 15-min pulses of graded doses of BAY-KB644 as indicated. Data represent results from 4 separate experiments (16 columns). Mean basal GtH level was $29.8 \pm 18.3$ $\mathrm{ng} / \mathrm{ml}$.

1989; Van Asselt et al, 1989; Mikolajczyk et al, 1990). It was shown in mammals, birds, and recently in fish that an increase in intracellular $\mathrm{Ca}^{2+}$ concentration is an essential step in $\mathrm{GnRH}$ action and that $\mathrm{Ca}^{2+}$ plays the role of second messenger in GnRH action (Conn et al, 1987; Huckle and Conn, 1988). We also proposed such a role for extracellular $\mathrm{Ca}^{2+}$ in $\mathrm{GnRH}$ action on GtH release in common carp (Mikolajczyk et al, 1990). The aim of the present study was to determine which type of calcium channel is responsible for $\mathrm{Ca}^{2+}$ influx during $\mathrm{GnRH}$ stimulation. The results presented here indicate that the stimulatory action of $\mathrm{K}^{+}$on $\mathrm{GtH}$ release resembles $\mathrm{GnRH}$ action, indicating that the mechanism of GnRH action may involve the activation of voltage-dependent calcium channels (VDCC). It has been shown (Nowycky et al, 1985) that in neuronal tissue, 3 types (L, N and T) of VDCC exist. Each type of channel exhibits different electrophysiological and pharmacological properties (Miller, 1987). It is also possible that in pituitary cells several types of calcium channel exist, as reported by Armstrong and Matteson (1985) in a clonal line of rat pituitary cells. In our experiments we used drugs from 2 chemical classes as VDCC blockers: dihydropyridine (DHP) and diphenylo- 
alkylamine (DPA). Nifedipine (DHP) specifically blocks the L-type VDCC (so-called DHP-sensitive). D-600 (DPA) also blocks the L-type VDCC. Since, in these experiments, nifedipine and D-600 did not inhibit either $\mathrm{K}^{+}$or $\mathrm{GnRH}$ action, it is clear that these 2 secretagogues ( $\mathrm{K}^{+}$and $\mathrm{GnRH}$ ) activate other types of VDCC than DHP- and DPA-sensitive (L-type) VDCC. To verify the role of other types of VDCC we applied cadmium ions $\left(\mathrm{Cd}^{2+}\right)$ which block indifferently all types of VDCC. Surprisingly, all the doses of $\mathrm{Cd}^{2+}$ used evoked a stimulation of GtH release. In this situation, to see the effect of $\mathrm{Cd}^{2+}$ on $\mathrm{sGnRH}$ and $\mathrm{K}+$ action we were obliged to look for a modification of $\mathrm{Cd}^{2+}$ stimulatory action by $\mathrm{sGnRH}$ and $\mathrm{K}+$. Using $s \mathrm{GnRH}$ as a secretagogue it was impossible to modify the profile and amplitude of the secretory response of the cells to $\mathrm{Cd}^{2+}$ (figs $5 \mathrm{~A}$ and $5 \mathrm{~B}$ ). However, elevated $\mathrm{K}+$ significantly changed the secretory response to $20 \mu \mathrm{mol} / / \mathrm{Cd}^{2+}$ (data not shown) and to $100 \mu \mathrm{mol} / / \mathrm{Cd}^{2+}$ (fig 6). When $\mathrm{Cd}^{2+}$ was applied at a concentration of $200 \mu \mathrm{mol} / \mathrm{l}$, no changes in $\mathrm{GtH}$ secretion were observed when $\mathrm{K}^{+}$was introduced. When these results were combined, it was concluded that $\mathrm{Cd}^{2+}$ inhibits and blocks $\mathrm{sGnRH}$ and $\mathrm{K}^{+}$action. It was however necessary to use a 10-times higher dose of $\mathrm{Cd}^{2+}$ to completely block the $\mathrm{K}^{+}$action than was the case for $s G n R H$. This is not surprising since elevated $\mathrm{K}+$ causes a total depolarization of the cell membrane and is probably a much stronger stimulatory factor than sGnRH. One of the possible explanations of the stimulatory effect of $\mathrm{Cd}^{2+}$ could be that different VDCC blocked by $\mathrm{Cd}^{2+}$ have a different influence on $\mathrm{GtH}$ release. For example, the blockade of a certain type of VDCC could inhibit GnRH and $\mathrm{K}^{+}$action while at the same time, blockade of another type of VDCC could stimulate $\mathrm{GtH}$ release. This hypothesis is strongly supported by results obtained using specific drugs acting on L-type of VDCC. At low doses nifedipine and BAY-K8644 had no effect on spontaneous and $\mathrm{GnRH}$ stimulated $\mathrm{GtH}$ release. However at higher doses (10 $\mu \mathrm{mol} / /$ and more) nifedipine (channel blocker) stimulated GtH secretion with high potency and BAY-K8644 (channel activator) inhibited GtH secretion. Combined, these results suggest that during the action of $\mathrm{Cd}^{2}+$ there was a blockade of the L-type of VDCC and, as in the case of nifedipine, there was a stimulation of GtH release. At the same time there was also a blockade of $\mathrm{N}$ and $\mathrm{T}$ channels provoking the inhibition of $\mathrm{K}^{+}$and $\mathrm{GnRH}$ action. In addition, a biphasic secretory response of the cells to $\mathrm{Cd}^{2+}$ also tends to support our hypothesis. Each time $\mathrm{Cd}^{2+}$ was applied, $\mathrm{GtH}$ stimulation was stronger at the end of the $\mathrm{Cd}^{2}+$ pulse than during $\mathrm{Cd}^{2+}$ administration. This suggests that the first phase of the response to $\mathrm{Cd}^{2}+$ was caused by a blockade of L-type VDCC and the second phase (after $\mathrm{Cd}^{2+}$ withdrawal) provoked by a rise in the blockade of, and/or the reactivation of $\mathrm{N}$ - and/or T-type VDCC. The fact that veratridine (an organic depolarizer) was able to stimulate $\mathrm{GtH}$ release only at very high doses and with very low potency indicates that this drug did not activate an exact type of VDCC responsible for GtH release. Another possible explanation of the surprising effect of NFD and BAY$\mathrm{K} 8644$ could be their nonspecific action when used at a high concentration (> 10 $\mu \mathrm{mol} / \mathrm{l})$. Drouva et al (1988) observed an inhibition of PRL and $\mathrm{GH}$ secretion from rat pituitary celis evoked by $100 \mu \mathrm{mol} / \mathrm{BAY}$. $\mathrm{K} 8644$, whereas concentrations from 0.01 up to $10 \mu \mathrm{mol} / \mathrm{l}$ were stimulatory. On the other hand, other data from the same laboratory (Enjalbert et al, 1988) show that BAY-K8644 at a concentration of 100 $\mu \mathrm{mol} / \mathrm{l}$ is less effective than at $10 \mu \mathrm{mol} / \mathrm{l}$ in stimulating PRL secretion but has no inhibitory effect on PRL release. Chang et al (1988) have also shown that BAY-K8644 at concentrations from $1 \mu \mathrm{mol} / /$ to $10 \mu \mathrm{mol} / /$ 
significantly increased basal $\mathrm{LH}$ release and enhanced $\mathrm{LH}$ responses to $\mathrm{GnRH}$.

Our results concerning the effect of D600 and nifedipine differ however from results obtained by other investigators in fish. Jamaluddin et al (1989) using static pituitary cell culture found a dosedependent inhibition of $\mathrm{GnRH}$-stimulated GtH release in murrel using D-600. On the other hand Van Asselt et al (1989) using perifused cattish pituitary fragments found no effect of D-600 on $\mathrm{GnRH}$-stimulated GtH secretion whereas $\mathrm{GnRH}$ action was inhibited by nifedipine. In our opinion such differences are provoked by different experimental approaches. It could be possible that in static cultures, only the prolonged phase of secretory response to GnRH was monitored as well as in the case of perifusion of pituitary fragments (Van Asselt et al, 1989) where fractions were rarely collected (10 $\mathrm{min}$ ) to find any effect on the first phase of the secretory response. In any case, results obtained on pituitary fragments are not so convincing since it is impossible to determine the level of drug action and to avoid possible interactions inside whole pituitary tissue.

In mammals and birds it is well established that in the prolonged phase of $\mathrm{LH}$ secretion under $\mathrm{GnRH}$ stimulation there is an influx of extracellular $\mathrm{Ca}^{2+}$ via voltagedependent calcium channels (VDCC). It was also shown that the L-type of VDCC (DHP- and DPA-sensitive) is responsible for this influx since specific L-type VDCC blockers inhibited or blocked the secretory response to $\mathrm{GnRH}$ (Hansen et al, 1987; Smith et al, 1987; Chang et al, 1988; Davidson et al, 1988; Smith et al, 1989). If the first (spike) phase of the secretory response to $\mathrm{GnRH}$ is concerned there is some controversy about the pathways as well as the sources of the $\mathrm{Ca}^{2+}$. Chang et al (1986), Hansen et al (1987) proposed the possible participation of $\mathrm{Ca}^{2+}$ mobilized from intracellular stores, whereas Conn et al (1987); Davidson et al (1988) and Smith et al (1989) found that there was an influx of extracellular $\mathrm{Ca}^{2+}$ via an other than VDCC, probably via so-called receptor operated channels (ROC). This second hypothesis is strongly supported by the findings of Mason and Waring (1985, 1986). They found that in bovine gonadotropes $\mathrm{GnRH}$ does not depolarize the cell membrane which is necessary to activate VDCC. On the contrary, Croxton et al (1988) have shown that in rat gonadotropes $\mathrm{GnRH}$ induces oscillatory membrane currents and this could be blocked by D-600. This finding tends to support the hypothesis of the intracellular origin of $\mathrm{Ca}^{2+}$ in $\mathrm{GnRH}$ action. These findings, together with the fact that several types of calcium channels exist could be an explanation for the striking differences among the results obtained on this subject.

\section{CONCLUSION}

The present findings indicate that $\mathrm{GnRH}$ action in carp is probably a voltagedependent process involving activation of $\mathrm{Cd}^{2+}$ sensitive VDCC. These channels are probably T- or N-type of VDCC. DHP- and DPA-sensitive VDCC (L-type) does not participate in $\mathrm{GnRH}$ and $\mathrm{K}^{+}$action. Activation of L-type VDCC leads to inhibition and their blockade to stimulation of $\mathrm{GtH}$ release. This could be part of other physiological pathways regulating $\mathrm{GtH}$ secretion in carp. In fish, dopamine (DA) was shown to be a gonadotropin releasing inhibitory factor (GRIF), and application of DA antagonists (pimozide, domperidone) stimulates GtH secretion and strongly potentiates the action of GnRH (Peter et al, 1986). It has been shown that neuropeptide $Y$ (NPY) also had a direct effect on GtH secretion in fish, and that its action depended on the 
stage of sexual maturity of the fish (ie inhibitory action in vitellogenic animals, and stimulatory action in freshly ovulated fish) (Breton et al, 1989, 1990). From our results it can be supposed that the inhibition of $\mathrm{GtH}$ release caused by activation of $\mathrm{L}$ type VDCC, reflects the action of DA or other drugs inhibiting the secretion of $\mathrm{GtH}$. It could also be speculated that $\mathrm{Ca}^{2+}$ serves as a second messenger for both $\mathrm{DA}$ and $\mathrm{GnRH}$, but its different transport through the cell membrane (different types of calcium channels) and probably different intracellular $\mathrm{Ca}^{2+}$ receptors lead finally to a different effect on $\mathrm{GtH}$ release. This hypothesis is currently under investigation.

\section{ACKNOWLEDGMENTS}

The authors extend their thanks to $M$ Gerber for the transport and care of fish. This study was supported by INAA, France.

\section{REFERENCES}

Armstrong CM, Matteson DR (1985) Two distinct populations of calcium channels in a clonal line of pituitary cells. Science 227, 65-67

Van Asselt LAC, Goos HJTh, Van Dijk W, Braas $J$ (1989) Role of calcium ions in action of gonadotropin-releasing hormone on gonadotropin secretion in the African catfish, Clarias gariepinus. Gen Comp Endocrinol 76, 46-52

Breton B, Kann G, Burzawa-Gerard E, Billard R (1971) Dosage radio-immunologique d'une hormone gonadotrope de carpe (Cyprinus carpio L). CR Acad Sci (Paris) Ser D 272, 1515-1517

Breton B, Mikolajczyk T, Danger JM, Gonnet F, Saint-Pierre S, Vaudry H (1989) Neuropeptide $Y$ (NPY) modulates in vitro gonadotropin release from rainbow trout pituitary glands. Fish Physiol Biochem 7, 77-83

Breton B, Mikolajczyk T, Weil C, Danger JM, Vaudry $H(1990)$ Studies on the mode of ac- tion of neuropeptide $Y$ (NPY) on maturational gonadotropin (GtH) secretion from perifused rainbow trout pituitary glands. Fish Physiol Biochem 8, 339-346

Chang JP, McCoy EE, Graeter J, Tasaka K, Catt KJ (1986) Participation of voltagedependent calcium channels in the action of gonadotropin-releasing hormone. $J$ Biol Chem 261, 9105-9108

Chang JP, Stojilkovic SS, Graeter JS, Catt KJ (1988) Gonadotropin-releasing hormone stimulates luteinizing hormone secretion by extracellular calcium-dependent and independent mechanism. Endocrinology 122, 8797

Chang JP, Freedman GL, De Leeuw R (1989) Participation of arachidonic acid metabolism in gonadotropin-releasing hormone stimulation of goldfish gonadotropin release. Gen Comp Endocrinol 76, 2-11

Conn PM, McArdle CA, Andrews V, Huckle WR (1987) The molecular basis of gonadotropinreleasing hormone $(\mathrm{GnRH})$ action in the pituitary gonadotrope. Biol Reprod 36, 17-35

Conn PM, Staley DD, Yasumoto T, Huckle WR, Janovick JA (1987) Homologous desensitization with gonadotropin-releasing hormone $(\mathrm{GnRH})$ also diminishes gonadotrope responsiveness to maitotoxin: a role for the $\mathrm{GnRH}$ receptor-regulated calcium ion channel in mediation of cellular desensitization. Mol Endocrinol 1, 154-159

Croxton TL, Ben-Jonathan N, Armstrong WMcD (1988) Gonadotropin-releasing hormone induces oscillatory membrane currents in rat gonadotropes. Endocrinology 123, 17831791

Davidson JS, Wakefield JK, King JA, Mulligan GP, Millar RP (1988) Dual pathways of calcium entry in spike and plateau phases of luteinizing hormone release from chicken pituitary cells: sequential activation of receptoroperated and voltage-sensitive calcium channels by gonadotropin-releasing hormone. $\mathrm{Mol}$ Endocrinol 2, 382-390

Drouva SV, Rerat E, Bihoreau C, Laplante E, Rasolonjanahary $\mathrm{R}$, Clauser $\mathrm{H}$, Kordon $\mathrm{C}$ (1988) Dihydropyridine-sensitive calcium channel activity related to prolactin, growth hormone, and luteinizing hormone release 
from anterior pituitary cells in culture: interactions with somatostatin, dopamine, and estrogens. Endocrinology 123, 2762-2773

Enjalbert $A$, Musset $F$, Chenard $C$, Priam $M$, Kordon C, Heisler S (1988) Dopamine inhibits prolactin secretion stimulated by the calcium channel agonist Bay-K-8644 through a pertussis toxin-sensitive $\mathrm{G}$ protein in anterior pituitary cells. Endocrinology 123, 406-412

Hansen JR, McArdle CA, Conn PM (1987) Relative roles of calcium derived from intra- and extracellular sources in dynamic luteinizing hormone release from perifused pituitary cells. Mol Endocrinol 1, 808-815

Huckle WR, Conn PM (1988) Molecular mechanism of gonadotropin-releasing hormone action. II. The effector system. Endocr Rev 9 , 387-395

Jamaluddin MD, Banerjee PP, Manna PR, Bhattacharya S (1989) Requirement of extracellular calcium in fish pituitary gonadotropin release by gonadotropin hormone-releasing hormone. Gen Comp Endocrinol 4, 190-198

Levavi-Sivan B, Yaron Z (1989) Gonadotropin secretion from perfused tilapia pituitary in relation to gonadotropin-releasing hormone, extracellular calcium and activation of protein kinase C. Gen Comp Endocrinol 75, 187-194

Mason WT, Waring DW (1985) Electrophysiological recordings from gonadotrophs. Evidence for $\mathrm{Ca}^{2+}$ channels mediated by gonadotropin-releasing hormone. Neuroendocrinology $41,258-268$
Mason WT, Waring DW (1986) Patch clamp recordings of single ion channel activation by gonadotropin-releasing hormone in ovine pituitary gonadotrophs. Neuroendocrinology 43, 205-219

Mikolajczyk T, Weil C, Epler P, Breton B (1990) Calcium ions as a mediator in GnRH action on gonadotropin release in the common carp (Cyprinus carpio L). Reprod Nutr Dev 30 , 483-492

Miller RJ (1987) Multiple calcium channels and neuronal function. Science 235, 46-52

Nowycky MC, Fox AP, Tsien RW (1985) Three types of neuronal calcium channel with different calcium agonist sensitivity. Nature 316, 440-443

Peter RE, Chang JP, Nahorniak CS, Omeljaniuk RJ, Sokolowska M, Shih SH, Billard R (1986) Interactions of catecholamines and GnRH in regulation of gonatotropin secretion in teleost fish. Recent Prog Horm Res 42, 513-548

Smith CE, Wakefield I, King JA, Naor Z, Millar RP, Davidson JS (1987) The initial phase of GnRH-stimulated LH release from pituitary cells is independent of calcium entry through voltage-gated channels. FEBS Lett 225, 247250

Smith CE, Davidson JS, Millar RP (1989) $\mathrm{Ba}^{2+}$ stimulation of luteinizing-hormone release demonstrates two mechanisms of $\mathrm{Ca}^{2+}$ entry in gonadotrope cells. Biochem $J 259,217$ 221 